\title{
DEVELOPMENT OF CITIZEN ADVOCACY MODEL USING A PARTICIPATORY APPROACH
}

\author{
Nafisah Laila*, Muhsin Ahmad, Siswanti Yuni \\ Faculty of Industrial Engineering, University of Pembangunan Nasional, \\ Yogyakarta, Indonesia \\ *E-mail: lailanafisah71@gmail.com
}

\begin{abstract}
The earthquake that occurred on May 26, 2006 in Yogyakarta resulted in 6,234 deaths and 46,148 displaced people. 37 heads of families occupied Winongo Ex Station in the former railway line in Glondong Tirtonirmolo village, Kasihan Bantul, Yogyakarta. The location occupied was the Sultan Ground (SG) land. In the course of time, the residents asked permission from the court to get the right to use the land or called Serat Kekancingan. The Yogyakarta Palace gave the answer that the Permit had been given to someone who in fact never lived, the land also became the object of buying and selling by irresponsible persons, and someone acted on behalf of the palace expert's interest and claimed to be the legitimate heir to the land. This study aims to develop the model of citizen advocacy to get the clarity on the status of land inhabited by using the Participatory Rural Appraisal (PRA) approach. The community is involved to actively participate in formulating the problems and finding the solutions to the problems. Research results show that the land status of the Yogyakarta Sultanate is under the authority of Panitikismo who has the right to issue a permit or kekancingan. The name in serat kekancingan can be changed or it is called liyeran. The people who want to use or obtain status submit a request through dukuh or the head of the village which is forwarded to the village, and approved by the Land and Spatial Agencies of the regency which is then sent to the Panitikismo of the Yogyakarta Palace. The association was formed to facilitate the coordination and management.
\end{abstract}

\section{KEY WORDS}

Participatory rural appraisal, sultan ground, advocacy, public service.

As many as 37 Family Heads occupied Winongo Ex Station precisely in the former railway line in Glondong Tirtonirmolo village, Kasihan, Bantul, Yogyakarta. The location occupied was the land of Sultan Ground (SG). The residents' houses built on SG land were mostly the only houses they had and not a second or alternative houses so that the residents were very dependent on the land. Even if there were residents' house which function as the second homes, new residents occupied land from buying from the first person who occupied the land. Some residents who occupied Ex Station of Winongo were recorded as poor families who received the benefit from PKH (Program Keluarga Harapan/ Family Hope Program) who needed help in the form of facilities.

Starting from the earthquake that shook Yogyakarta on May 27, 2006 which devastated residential areas, this earthquake disaster raised new problem which was the condition that the residents' houses were destroyed. The house that used to be occupied by a number of families was then divided by inheritance by family consultation. Finally, some residents who did not get the land got the rice fields, which eventually ended up for medical expenses. Some residents who then did not have land to build temporary houses then used ex-railroad land with the status of Sultan Ground. The land that was occupied turned out to have been plotted by irresponsible parties and who acted on behalf of local officials and traded.

In the course of time, residents asked permission from the court to obtain land use rights or serat kekancingan. The Yogyakarta Palace gave the answer that a permit had been given to someone who had never appeared until now, plus the land had become an object of sale and purchase by irresponsible persons. Lately there are people that claimed to come from Sri Sultan Hamengkubuwono VII who claimed to be the heirs as well as the legal 
owners of the land or called as eigendom rights. There have been many reports from the citizens who felt cheated by these people and lost up to ten million rupiahs by buying the right to use the land and depositing some money to them.

Based on the problem explained previously, this study aimed to formulate an advocacy model for the citizens to get clarity on the status of land that is currently inhabited and unravel the tangled thread that occurred in the area. Concerning the complexity of the problem that occurred, then the approach to be taken is to use the Participatory Rural Appraisal (PRA) method by inviting the community to participate in formulating problems to find the solution to problem. The time to conduct this research was divided into 3 years. The first year was conducting a problem assessment and activity advocacy planning. The second year was the implementation of activities and advocacy, and the third year was assisting the community.

The aim to be achieved in this study is that the citizens have the clarity on the status of the land occupied by the possession of surat kekancingan or official certificate from the Yogyakarta palace. However, the problem faced was so complex that it required an appropriate advocacy model, which was based on the results of assessments that had been explored directly from the community as a program target with related parties such as the Village Government, Youth Organization and Community Groups. This approach is known as Participatory Rural Appraisal (PRA), which means directly involving the community and related parties in the formulation of their problems, exploring the right solutions, providing training and mentoring on the implementation of the formulation of the empowerment model produced.

The model that was formed was directed to be able to realize the life of the citizens of Winongo ex-railroad station which occupied the Sultan Ground which is safe, peaceful and secure by acquiring status over the land used. This model is a policy formulation that can be taken by citizens in order to obtain a certificate or a letter of use rights on the land of the Yogyakarta palace as legality for land use and to avoid misuse or fraud from irresponsible persons.

\section{LITERATURE REVIEW}

Participatory Rural Appraisal (PRA) to develop community participation [1]. With the basic ideals that advocacy activities are ultimately developed and owned by the community themselves because they are more familiar and know the problem faced better. The community is directed to be able to see the conditions of their own point of view [2]. This model also helps to educate the social problem of the community. It also functions as the empowerment of the role of facilitator and activist to fight for a better goal of life together.

Social problems are important to solve because people, especially children, are more vulnerable to being affected, which can result in weak health, poor mental health, cognitive problems and limited life opportunities [3]. Settlement of social problems must involve the people themselves by recognizing the potential to improve the abilities [4]. The community empowerment process that is implemented is to strive for the community to develop their own abilities so that the ability they have is able to free them to overcome problems and make decisions independently [5].

The process of community empowerment is carried out by strengthening the capacity of the community through providing access to resources, and creating accommodative services [6]. The results of the field survey show that residents have not been fully prepared for changes in which they have limitations including the ability of human resources, the lack of infrastructure, the limited access to information and the income that is largely supported by the agricultural labor. This is consistent with the tendency that indigenous people tend to be marginalized and have limitations [7].

The basic concept of participatory research is to know the challenges/ problems faced by society and find solutions [8]. Empowerment efforts are based on meeting the needs of the community itself so that the community is able to develop and overcome its own 
problems independently, in a sustainable manner [5], so as to produce targeted solutions in accordance with the local and regional needs [9].

The PRA technique is a direct learning process of the community to optimize selfawareness and responsibility [10], focusing on spatial and socio-economic aspects to get overall efficiency [11] which is packaged in the form of Focus Group Discussion (FGD) in its participatory approach [12].

Yogyakarta Province has privileges in the State of Indonesia in managing its own household, namely the procedures for filling positions, duties and authority of the governor and deputy governor; government institutions, culture, land and spatial planning [13]. The palace land is sultan's land which is used and inhabited by sultan and his family [14].

The Yogyakarta Palace was established after the Giyanti agreement on February 13, 1733 which divided the kingdom into 2 namely Surakarta Sunanate and Yogyakarta Sultanate [15]. The Surakarta and Yogyakarta regions used to be regions of swapraja, which is the name for the area ruled by the Dutch East Indies. The highest authority over land ownership is king and there is nothing at the same level of property rights [16].

The Law No. 5 of 1960 concerning the Basic Agrarian Regulations states that the rights and authority of the earth, water, and swapraja are removed and moved to the state [17]. Swaprajal self-government land is for the government, heirs of the authorities, and is distributed to the people through a land redistribution program [18]. Sri Sultan HB IX on October 12, 1983, as the Governor of the Special Region of Yogyakarta said that the authority of agrarian affairs was aligned with the national agrarian policy so that in Yogyakarta, it was held as a matter of deconcentration because it included the substance of the special features of the Yogyakarta Special Region [17].

\section{METHODS OF RESEARCH}

The object of this research was families who did not own land and occupied Winongo Ex Station in the former railway line in Glondong Tirtonirmolo village, Kasihan, Bantul, Yogyakarta. The location of the research was in Glondong Tirtonirmolo village, Kasihan, Bantul, Yogyakarta.

The data used in this study are primary data and secondary data. The primary data are in the form of data obtained directly through observation, interviews, surveys, assessments and direct observation of the object to be studied. Survey was conducted to dig the information from the questionnaires on 32 residents in the area who had the status of land which belonged to the Yogyakarta Sultanate to find out the licensing and management patterns, and the rules on the use of the Sultan Ground in the palace area. Whereas the secondary data are in the form of data obtained indirectly or the data obtained from the local government.

\section{RESULTS OF STUDY}

Regional Data Creation. The results of data collection through Focus Group Discussions (FGDs) and questionnaires of the residents provide an overview of the following conditions.

Based on the age category according to the Ministry of Health, the graphic above shows that the majority of Glondong residents are elderly, which is $66 \%$, followed by adults $31 \%$ and teenagers $3 \%$. This shows that most of the residents of the Sultan Ground in Glondong are elderly.

The graph above shows that the residents of Sultan Ground of Glondong population are divided into 2 which are 50\% indigenous people and 50\% migrants. These migrants usually came from ex-refugees from the Yogyakarta earthquake in 2006 who no longer had a place to live.

The picture above shows the level of education of Glondong residents. The majority of them are high school graduates which are 53\%, 19\% junior high school, $13 \%$ elementary school, $3 \%$ undergraduate and those who do not go to school are $12 \%$. The community has 
the opportunity to develop according to the level of education and understand the process of citizens' rights status. Providing education and understanding about politics and citizenship.

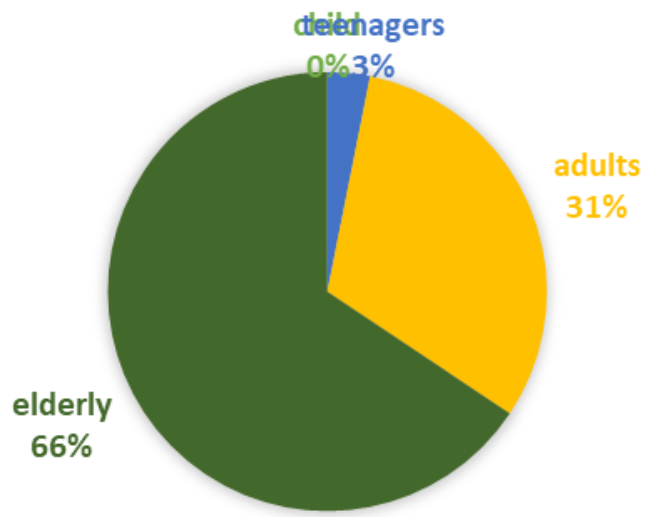

Figure 1 - The chart of the residents based on the age

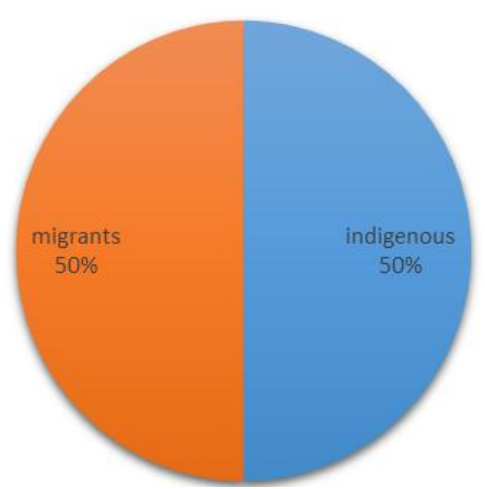

Figure 2 - The chart of the indigenous residents and the migrants

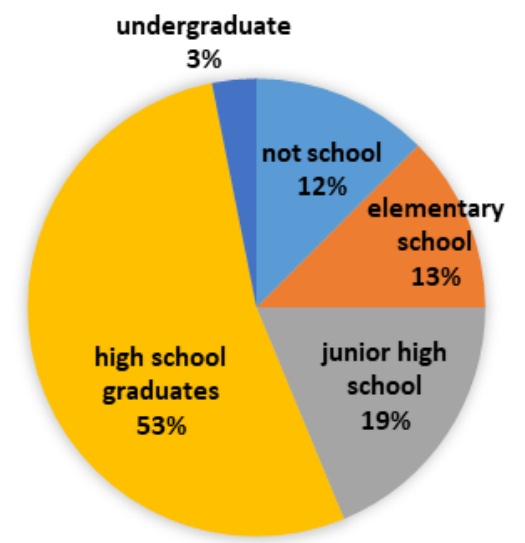

Figure 3 - The education of Glondong residents

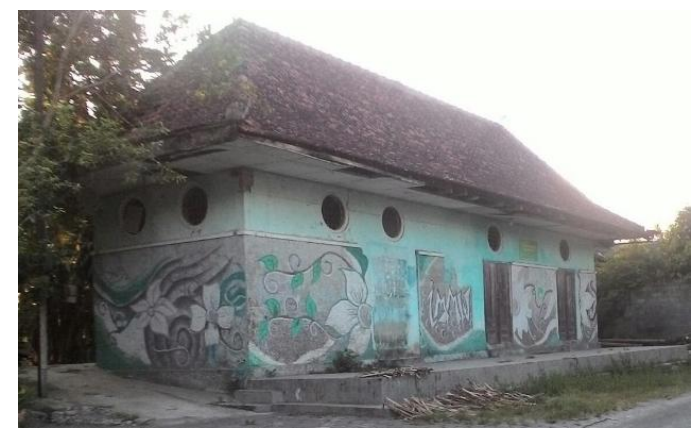

Figure 4 - Winongo Ex Train Station 
Glondong Village is located on Jalan Bantul Km 6.5. It is often called Winongo Village because there is a Winongo Station. Winongo Station is an inactive train station in Glondong, Tirtonirmolo, Kasihan, Bantul. The station is included in the Operational Area VI of Yogyakarta built by the Netherlands-Indische Spoorweg Maatschappij (NIS), the first railway company in the Dutch East Indies, the construction of the station was started in 1895 and completed in 1912-1919 as the development of the Yogyakarta - Sewugalur crossing railway line.

Winongo Station is close to tMadukismo Sugar Factory so that a branch line was built into the factory for transportation. In 1973, the station and its line were closed. Winongo station building was damaged when an earthquake shook Bantul district in 2006 and then the residents took the initiative to fix it. Currently the station building is still there and is used by residents as the place for meeting centers and activities of youth organizations.

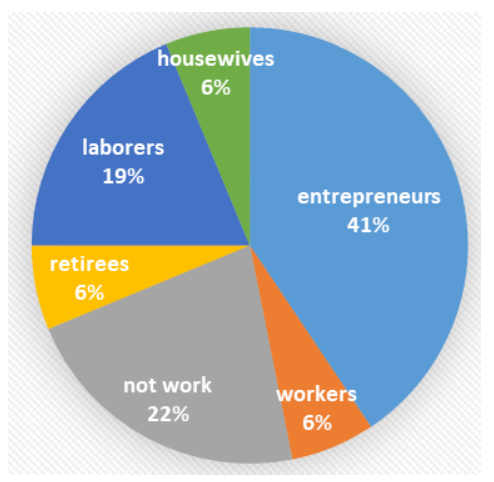

Figure 5 - The occupation of the residents

Most of the residents of Glondong village work as entrepreneurs or merchants which are $41 \%$. There were $22 \%$ of them who do not work due to the old age. There were $19 \%$ laborers, $6 \%$ workers, $6 \%$ retirees and the remaining $6 \%$ are housewives. The people who live in Sultan Ground are middle to low-income people who need assistance for family welfare.

The Sultan Ground land occupied by the residents of Glondong village is classified as densely populated land and there are still many remaining railroad tracks from Winongo station so that it is not possible to make agricultural land there as the main livelihood, but it is still possible to make a garden with fruit trees even though it is not wide.

Table 1 - The usage of land functions

\begin{tabular}{|c|c|}
\hline Functions & Area \\
\hline House & 2380 \\
\hline Garden & 100 \\
\hline Warehouse & 60 \\
\hline Shop & 40 \\
\hline
\end{tabular}

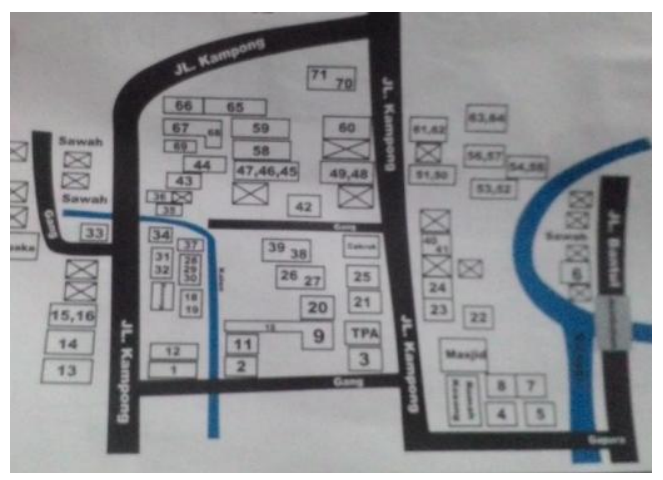

Figure 6 - The sketch of Glondong village 
The data above shows that the residents use the majority of land for housing and some small parts for gardens, warehouses, and businesses.

In the sketch of the Glondong village, the majority of the area is occupied by residents' houses, divided into several RT areas, and bordered by rivers on the east side.

Glondong Village is located in the government area of Tirtonirmolo Village, Kasihan District, Bantul Regency, Yogyakarta Province. Glondong Village is divided into 3 RTs and it has Youth Organization, PKK (women organization), and many of the residents are the members of the Street Vendors Association (Asosiasi Pedagang Kaki Lima/ APKLI).

The results of processing potential data owned by residents of Glondong village are:

- The majority of the population has high school education, which is $53 \%$, which allows them to understand things;

- The age of the $66 \%$ population is old so that they have more maturity in dealing with conflict;

- Half or $50 \%$ of the population are indigenous people who are very familiar with environmental conditions;

- As many as $31 \%$ of the residents stated that they knew the procedures for obtaining licenses for the use of the Sultan Ground;

- As many as $25 \%$ of the residents have obtained serat kekancingan or a land use permit from the Yogyakarta palace.

The problem faced by the residents of Glondong Village is:

- Citizens who do not have serat kekancingan or the permission to use sultan's land are $75 \%$;

- Citizens who do not know how to obtain serat kekancingan are $69 \%$;

- The number of elderly people is $66 \%$ who are unproductive and resigned.

Based on the results of the data, a SWOT analysis was made as below.

Table 2 - SWOT Analysis

\begin{tabular}{|c|c|c|}
\hline & Strength (S) & Weakness (W) \\
\hline 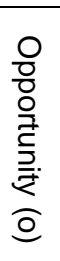 & $\begin{array}{l}\text { Utilizing the education that they have to } \\
\text { access legal clarity; } \\
\text { Utilizing the equality of the residents to collect } \\
\text { the data; } \\
\text { Residents give education and understanding } \\
\text { to each other, especially to those who do not } \\
\text { know the clarity of the land status }\end{array}$ & $\begin{array}{l}\text { Providing education about the land status to the } \\
\text { residents; } \\
\text { Assisting the residents, especially the elderly in the } \\
\text { management; } \\
\text { Forming a community to help each other }\end{array}$ \\
\hline 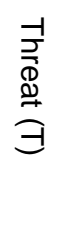 & $\begin{array}{l}\text { Use the village network to convey aspirations } \\
\text { up to the district level and the National Land } \\
\text { Agency; } \\
\text { Using the bureaucracy and government lines } \\
\text { to be able to access the land section or } \\
\text { panitikismo of the Yogyakarta palace }\end{array}$ & \\
\hline
\end{tabular}

Based on the results of the SWOT analysis above, an advocacy model can be formulated as follows:

- Collect data on residents of Glondong village who occupy the Sultan's land;

- Data collection includes the identity of the population, the area of land occupied and the location plan;

- Data collection is sent to the village head to get a certificate of land occupied that it is not in dispute;

- Collectively submit a request letter to obtain serat kekancingan to the sultan ground manager, in this case the panitikismo of the Yogyakarta palace, which is directed to KGP Hadiwinoto Kawedanan Hageng Punokawan Wahono Satrokriyo Keraton, and acknowledged by the local government; 
- Submit a letter of ownership rights to the National Land Agency (Badan Pertanahan Nasionall BPN);

- Form a community of residents of Sultan Ground to help each other and keep them from unwanted people.

\section{CONCLUSION}

Based on the results of the Study with a Participatory Approach in Glondong Tirtonirmolo Village, Kasihan, Bantul, Yogyakarta, it can be concluded that:

- The majority of residents still do not have a permit to use Sultan Ground which can cause problems in the future;

- To get serat kekancingan, it is necessary to collect data on the residents and the occupied land;

- Submitting a letter of application for serat kekancingan to Panitikismo of the Yogyakarta palace and a letter of ownership rights of benefit to National Land Agency/ BPN;

- Forming a community to provide education, understanding, and mentoring to the residents.

\section{ACKNOWLEDGEMENTS}

We would like to thank the Ministry of Research, Technology and Higher Education for organizing the PTUPT Research Program so that this publication can be funded, as well as the Institute for Research and Community Service (LPPM) of UPN "Veteran" Yogyakarta which has facilitated the implementation of this research.

\section{REFERENCES}

1. Muhsin, D. S. Hapsoro, and Y. Siswanti, "Community-Based Poverty Alleviation Using Participatory Rural AppraisaL," Russ. J. Agric. Socio-Economic Sci., vol. 6, no. June, pp. 112-118, 2018.

2. Muhsin, A. Ristono, and Y. Siswanti, "The Development Of Community-Based Women's Empowerment Model for Poor Wives Using Participatory Poverty Assessment Method," Russ. J. Agric. SOCIO Econ. Sci. Sci., vol. 7, no. July, pp. 295-300, 2018.

3. Najman et al., "The inter- and intra- generational transmission of family poverty and hardship adversity): A prospective 30 year study," PLoS One, vol. 13, no. 1, pp. 1-13, 2018.

4. Olawepo, "Using Participatory Rural Appraisal to explore coastal fishing in Badagry villages, Nigeria," Environmentalist, vol. 28, no. 2, pp. 108-122, 2008.

5. Muhsin, L. Nafisah, and Y. Siswanti, Participatory Rural Appraisal (PRA) for Corporate Social Responsibility (CSR), 1st ed., no. I. Yogyakarta: Deepublish, 2018.

6. T. Harpham and L. Anelay, "After roads and dams: What role for engineers in the poverty reduction strategies of bilateral development agencies?," J. Int. Dev., vol. 11, no. 6, pp. 811-823, 1999.

7. Mohindra, D. Narayana, and S. Haddad, "'My story is like a goat tied to a hook.' Views from a marginalised tribal group in Kerala (India) on the consequences of falling ill: A participatory poverty and health assessment," J. Epidemiol. Community Health, vol. 64, no. 6, pp. 488-494, 2010.

8. Getchell et al., "Raising livestock in resource-poor communities of the North West Province of South Africa - a participatory rural appraisal study," vol. 73, pp. 177-184, 2002.

9. Li, H. Long, S. Tu, and Y. Wang, "Analysis of income inequality based on income mobility for poverty alleviation in rural China," Sustain., vol. 7, no. 12, pp. 16362-16378, 2015. 
10. Castelli and E. Bresci, "Participatory rural appraisal for Diagnostic Analysis of spate irrigation systems in Raya Valley, Ethiopia," J. Agric. Rural Dev. Trop. Subtrop., vol. 118, no. 1, pp. 129-139, 2017.

11. Indrizal, "Pengkajian keadaan perdesaan secara partisipatif participatory rural appraisal (pra): suatu pengantar pengenalannya," Jantro J. Antropol. isi-isu Sos. budaya, vol. 15, no. 2, pp. 39-49, 2014.

12. Uddin and N. Anjuman, "Participatory rural appraisal approaches: an overview and an exemplary application of focus group discussion in climate change adaptation and mitigation strategies," Int. J. Agric. Res. Innov. Technol., vol. 3, no. 2, pp. 72-78, 2013.

13. Hasim, "Politik Hukum Pengaturan Sultan Ground Keistimewaan Yogyakarta Dan Hukum Tanah,” Arena Huk., vol. 9, no. 2, pp. 207-224, 2016.

14. Setiawati, Dari Tanah Sultan Menuju Tanah Rakyat; Pola Pemikiran, Penguasaan, dan Sengketa Tanah di Kota Yogyakarta setelah Reorganisasi 1917, 1st ed. Yogyakarta: STPN Press, 2011.

15. Soekanto, Sekitar Jogjakarta 1755-1825: Perdjanjian Gianti-Perang Dipanegara. Djakarta: Mahabarata, 1952.

16. Harsono, 2003, Hukum Agraria Indonesia, Sejarah Pembentukan Undang-Undan Pokok Agraria, Isi dan Pelaksanaannya. Jakarta: Djambatan, 2003.

17. Fernando, Eksistensi Sultan Ground dalam Hukum Tanah Nasional di Desa Srigading Kecamatan Sanden Kabupaten Bantul Provinsi Daerah Istimewa Yogyakarta, vol. 13, no. 2. 2010.

18. Ashari, 2008, Status Tanah-Tanah Kasultanan Ternate Di Provinsi Maluku Utara (Tinjauan Juridis Hukum Tanah Nasional). Yogyakarta: Faculty of law UII, 2008. 